\title{
GLOBAL COVID-19: WHAT ISLAMIC ECONOMIC AND FINANCE CAN DO? INDONESIA EXPERIENCE
}

\author{
Azwar Iskandar ${ }^{1 *}$, Bayu Taufiq Possumah ${ }^{2}$, Khaerul Aqbar ${ }^{3}$ \\ *Corresponding Author \\ ${ }^{1}$ Sekolah Tinggi Ilmu Islam dan Bahasa Arab (STIBA), Makassar, South Sulawesi, Indonesia, azwar.iskandar@gmail.com \\ ${ }^{2}$ Institut Agama Islam Tazkia, Bogor, West Java, Indonesia, btaufiq@gmail.com \\ ${ }^{3}$ Sekolah Tinggi Ilmu Islam dan Bahasa Arab (STIBA), Makassar, South Sulawesi, Indonesia, khaerul@stiba.ac.id
}

\begin{abstract}
Pandemic of COVID-19 has shocked and spread all over the world, including Indonesia. This research was conducted with the aim to lay out the role of Islamic economic and finance policies, as well as to propose a number of solutions which could be offered to solve various problems in time of the COVID-19 pandemic in Indonesia. By using descriptive qualitative approach, this research attempts to analyse various concepts that found in the research process trough content analysis techniques and library research. The results show that within the framework of Islamic economic and finance, some strategies that can be employed to dispose the social impact of COVID-19 such as: (1) distribution of direct cash assistance from zakat and infaq, collected by zakat and other social institutions; (2) strengthening infaq programs for various needs; (3) strengthening waqf programs, including cash waqf for social waqf projects, productive waqf, combination of social-productive waqf, or cash waqf linked sukuk; (4) superior venture capital assistance for the business sectors or Micro and Small Enterprises (MSEs); (5) the qard al-hasan scheme; (6) improvement of Islamic economic and finance literacy; and (7) the development of Islamic financial technology. If the above programs using Islamic economic and finance instruments could really be encouraged, the economic surplus would be reestablished and the acceleration of economic recovery could be realized, while at the same time reducing poverty and supporting the achievement of equitable distribution of income and wealth.
\end{abstract}

Keywords: Islamic economic and finance, Islamic social finance, COVID-19, zakat, infaq, waqf

Received

July 22, 2021

To cite this article:

\section{Revised}

September 9, 2021
Accepted

September 14, 2021
Published

September 30, 2021

Iskandar, A., et al. (2021). Global covid-19: what Islamic economic and finance can do? Indonesia experience. IJIBE (International Journal of Islamic Business Ethics), 6 (2), 119-134. http://dx.doi.org/10.30659/ijibe.6.2.119-134

\section{INTRODUCTION}

Wuhan, a city in the People's Republic of China (PRC), has suddenly become famous throughout the world. In the city of about 9 million people, the Corona virus attack (COVID19) began. The virus has spread not only in mainland of China but also to more than 180 countries/regions in the world since March 2020. The World Health Organization (WHO) finally announced the status of a global pandemic on March 11, 2020. Based on existing data by China, COVID-19 slowdowns the Chinese economic growth from $6.1 \%$ last year to only around 3.8\% this year, provided that the pandemic does not get worse. On the contrary, there are still many pockets of growth by China's government to support the economy such as tax cuts, and boost liquidity in the financial system.

As the country with the second largest economy in the world, the PRC experienced an economic downturn which naturally affected the global economy. The negative impact of the COVID-19 pandemic quickly spread throughout the world, not only because of its infectious 
virus, but also because of the mobility of the world's population and the global value chains which actually have very high levels of connectivity. Several credible research institutions around the world predict that the spread of this pandemic lead to adverse effects pandemic on the global economy. World economic institutions such as JP Morgan predicts a world economy of minus $1.1 \%$ in 2020 , EIU predicts minus $2.2 \%$, Fitch predicts minus $1.9 \%$, and the IMF predicts the world economy of minus 3\% in 2020 (Baldwin \& Mauro, 2020).

In Asia, according to the Minister of Finance of the Republic of Indonesia, Sri Mulyani Indrawati, Indonesia predicted in the worst case scenario to reach minus $0.4 \%$ of growth (Iskandar et al., 2020) and Malaysia's economy is projected to contract by 3.1 percent in 2020 (World Bank's Malaysia Economic Monitor). The World Bank also estimates that nearly 35 million people will remain in poverty in line with close on 24 million people in East Asia and the Pasific stop their businesses. The number of people living in extreme poverty will increase to 922 million worldwide (Fernandes, 2020).

The Center of Reform on Economics (CORE) reports on economic conditions during the COVID-19 pandemic. The surge in the number of sufferers with a high fatality rate in the past month is very worrying. In Indonesia, the response of the government and the community that made prevention efforts, such as school closures, work from home, especially formal sector workers, delays and cancellations of various government and private events, made the wheels of economic turnover slow down. Private consumption, which accounts for nearly $60 \%$ of national economic movements, is certain to contract. Retail sales, both in traditional and modern markets, are certain to fall. In fact, before the COVID-19 case was identified in Indonesia, the Real Sales Index data released by Bank Indonesia already showed a contraction of 0.3\% in January 2020 (Muzakki, 2020).

There are at least two main indicators of the impact of COVID-19 on the Indonesia's financial market. First, on March 23 the exchange rate of the Indonesian Rupiah against the U.S. Dollar reached 16,575 rupiah per USD, the weakest since the Asian financial crisis of 1998, despite Bank Indonesia's best efforts to control the local currency. Secondly, the Jakarta Composite Index (JKSE) value that was steady around 6,200 until late January 2020 saw a huge decline to 4,000 in the last week of March before rebounding to around 4,500 in early April. (Sukmana, Indrawan, and Ajija, 2020).

In the real sector represented by the Gross Domestic Product (GDP), the official figure has not been revealed for the first quarter of 2020. However, Bank Indonesia revised its economic growth projection to be in the range of 4.2-4.6\% in 2020, lower than 2019's growth rate of $5.02 \%$. Recovery is expected to take place in 2021, which will be around $5.2-5.6 \%$ (Bank Indonesia, 2020).

Among the forms of efforts that have been called for and carried out by the world in order to reduce the spread of this pandemic is social or physical distancing. But unfortunately, this movement has had an influence on the decline in overall economic activity. Furthermore, this chain of economic decline shows that the disaster caused by the COVID-19 virus to the economy not only caused a (large) downturn to real economic fundamentals, but also undermined the smoothness of market mechanisms and formed a kind of 'barrier wall' between demand and supply. Furthermore, it caused a chain reaction towards the decline in the real economy. A contraction in supply, which led to a contraction in demand, ultimately eliminates the economic surplus (Institut Tazkia, 2020). 
Given that vital aspects of the economy, namely supply, demand and supply-chain have been disrupted, the impact of the crisis will be felt equally across all layers or levels of society. Because the resilience of each society layer or level is different, the middle to lower economic groups, especially micro and informal with daily income, naturally become the most vulnerable group affected. The impact in the real sector will then spread to the distressed financial sector because a large number of investees will have difficulty paying to investors.

With the above conditions, a big question arises: how can Indonesia get through it? What does this nation have to be able to survive in the midst of a wave of uncertainty when it will end? A glimmer of big hope is true within the Indonesian people. As a country with the largest Muslim population in the world, Muslims can give their best role through various forms or models of philanthropy in Sharia Economics and Finance. The term philanthropy comes from Greek, namely philos (loving) and anthropos (mankind). Literally, philanthropy is the conceptualization of the practices of giving, services and association that are voluntary to help other people who are in need as an expression of the feeling of love. In general, philanthropy is defined as a voluntary action for the public's good. There are two models of philanthropy that are known, namely traditional philanthropy based on charity and social justice philanthropy (Sakni, 2013). Islam as a religion that teaches humans to love each other, to show affection and sympathy, has a configuration of charity or philanthropy from its teachings (Uyun, 2015). Among the teachings are in the forms of orders to give infaq, sadaqah, zakat, and waqf, which can have implications in addition to increasing faith in God, fostering a high sense of humanity, eliminating miserly greedy and materialistic human nature, fostering peace of life, cleaning and developing possessions, also can overcome various problems in social life, economy, education, environment (Kasdi, 2016) and other aspects of life. This role is expected to overcome the economic shocks that occur and the whole society, especially Muslims, can participate in contributing to recovering these shocks.

Departing from this, the study was conducted with the aim to lay out a number of solutions and the role of Islamic economic and financial policies that can be offered in the face of the COVID-19 pandemic in Muslim majority country like Indonesia and Malaysia. A number of previous studies (Fanidi et al., 2020; Gershon et al., 2020; Gros et al., 2020; Jewell et al., 2020; Jones et al., 2020) were only see the strategies and measures in anticipation of the impact of pandemic on the economy in conventional terms. This is the gap of the research regarding to issue. As for this, research describes measures and policies which can be done in Islamic economic and financial terms.

\section{LITERATURE REVIEW}

At the beginning of its emergence, with the rule of physical distancing or tightening and restriction of other community activities, this COVID-19 pandemic gave a shock to the supply side of the economy. This chain of economic decline shows that the disaster caused by the COVID-19 virus to the economy not only caused a (large) downturn to real economic fundamentals, but also undermined the smoothness of market mechanisms (Surico \& Galeotti, 2020). Given that vital aspects of the economy, namely supply, demand and supplychain have been disrupted, the impact of the crisis will be felt equally across all layers or 
levels of society, especially micro and informal with daily income, naturally become the most vulnerable group affected.

As a country with the largest Muslim population in the world, Muslims can give their best role through various forms or models of philanthropy in Islamic Economics and Finance. Islam as a religion that teaches humans to love each other, to show affection and sympathy, has a configuration of charity or philanthropy from its teachings. Among the teachings are in the forms of orders to give infaq, sadaqah, zakat, and waqf, which can have implications in addition to increasing faith in God, fostering a high sense of humanity, also can overcome various problems in social life, economy, education, and other aspects of life. This role is expected to overcome the economic shocks such as poverty and inequality that occur and the whole society, especially Muslims, can participate in contributing to recovering these shocks.

Poverty alleviation and inequality reduction have been embedded in Islam and Islamic economics through many different means. Sadeq (1997) described "Poverty Eradication Scheme of Islam", while Obaidullah (2008) described "Islamic Approach to Poverty Alleviation". Sadeq (997) stated that Islamic approach to poverty eradication comprised of three sets of measures, namely: i) positive measures, including income growth, functional distribution of income and equal opportunity; ii) preventive measures, including control ownership and prevention of malpractice; and iii) corrective measures, fosters wealth transfers from the have to the needy including zakat as compulsory transfer, and charity and state responsibility as possiible recommended transfer." Obaidullah (2008) in other words e stated that the Islamic principles of poverty alleviation include: a) charity; b) economic empowerment; c) debt avoidance; d) cooperation and solidarity; e) family cohesiveness; f) Shari'ah compliance of contracts; and g) Islamic norms and microfinance best practices.

Ascarya $(2017,2020)$ also stated that under Islamic economic system, Islamic finance is not only about commercial finance, but also covers social finance with similar objective to achieve falah (wellbeing and prosperity in this world and in the hereafter). Meanwhile, Islamic commercial finance is inherently stable, while Islamic social finance could simultaneously achieve triple bottom-line. Moreover, Islamic finance encompass Islamic commercial finance (such as partnership, real activities, governance and ethical), as well as Islamic social finance (such as zakat and waqf), which could addressed SDG's goals. 


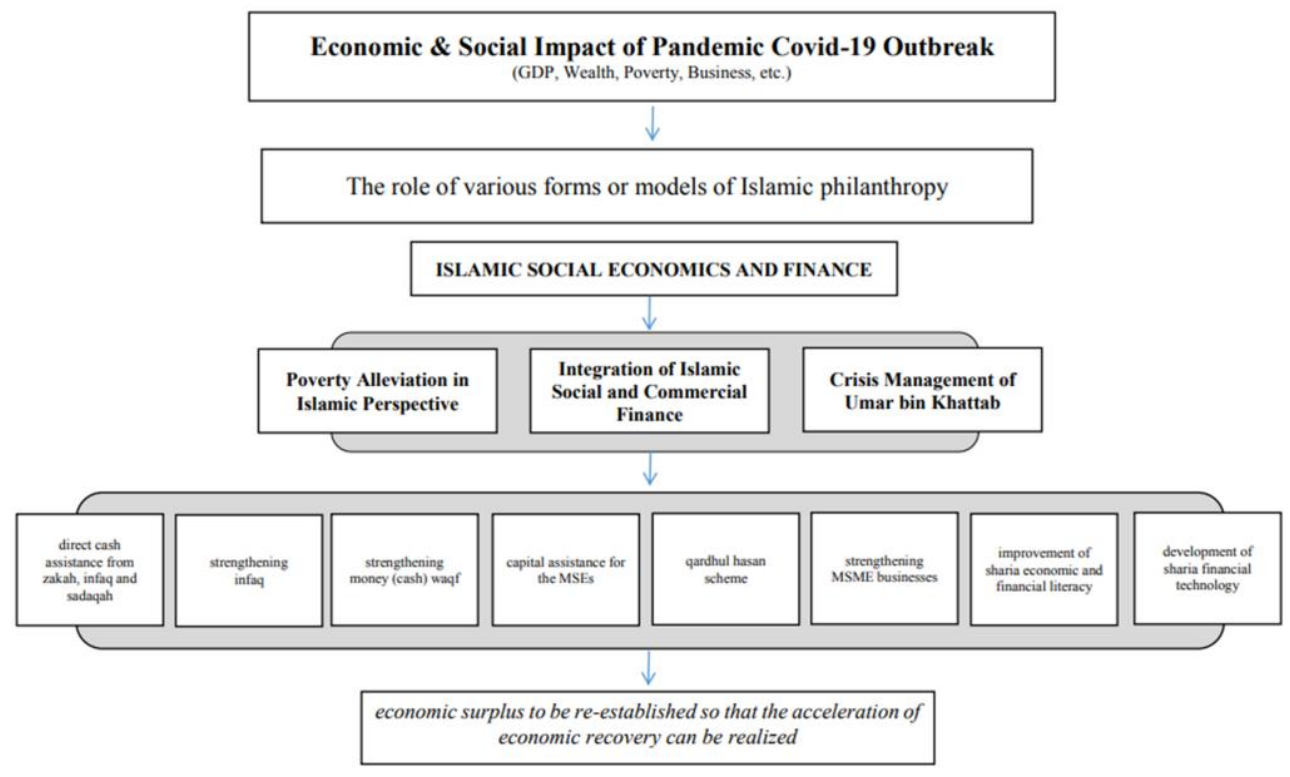

Figure 1: Conceptual Framework

Source: Ascarya, (2017, 2020); Obaidullah (2008); Sadeq (1997); Al-Haritsi et al. (2006) (modified by authors)

In crisis context, the management of the Ramadah crisis undertaken by Umar bin Khattab, second great calliph in Islam, could be a reference to the crisis in the following days, including in the current COVID-19 pandemic. The utilization of all existing resources through the role of zakat, infaq and șadaqah as well as relationships built throughout the country will be a way to solve the crisis of hunger, poverty and health. Umar's policy that always provide ease and flexibility to the innovation in his day, especially with regard to the object of zakah, as mentioned above. This policy is based on the principle of taisir (providing convenience) for the innovation and also see the benefits that can be reached from the Mustahik. In its policy, there are times when Umar ibn Khattab accelerated the withdrawal of zakah, and in other conditions Umar delay the withdrawal of zakah from Muzakki (AlHaritsi, 2015). In the context of zakah withdrawal delay, Umar ibn Khattab issued a policy to not collect zakah from the Muslim cattle in the event of a disaster that struck the medina and its surroundings, namely the year of the Famine called the Ramadah year. However, the following year, after the condition of the area has improved, Umar ibn Khattab ordered to withdraw two years from the population who became the innovation in the region, namely their zakah that year and zakah of the previous year that had been postponed. The problem of the synchronization policy and the postponement of zakah on the basis of the welfare for the mustahik as mentioned above, is in fact very relevant to the policy of the zakah management in the Muslim countries of the world, specialized in the conditions and context of the current pandemic crisis. The payment of zakah by the innovation can be eliminated before even a year and after sufficient the ratio, given the great benefit for the poor and needy people affected by the pandemic outbreak of COVID-19. 
All of the above-mentioned approaches, can essentially be a solid foundation to devise several steps and efforts to address the crisis caused by the COVID-19 pandemic in Indonesia through a model of philanthropy in Islamic economics and social finance (see Figure 1).

\section{METHODS}

This research uses descriptive qualitative approach using content analysis techniques and library research. Refer to Schreier (2012), qualitative content analysis is one of the several qualitative methods for analyzing data and interpreting its meaning. As a research method, content analysis represents a systematic and objective means of describing and quantifying phenomena (Downe-Wamboldt, 1992; Schreier, 2012), the data then reduced to concepts that describe the research phenomenon (Cavanagh, 1997; Elo \& Kyngäs, 2008; Hsieh \& Shannon, 2005) by creating categories, concepts, a model, conceptual system, or conceptual map (Elo \& Kyngäs, 2008; Morgan, 1993; Weber, 1990). The content analysis done and supported by research library to capture secondary data obtained from research article results and reference books that discussing topics related to the subject matter of research (Iskandar \& Aqbar, 2019).

\section{RESULT AND DISCUSSION}

The COVID-19 pandemic is far more than a health crisis: it is affecting in almost levels of society and economy at their core especially poor vulnerable groups, poor informal group, and micro and small businesses group (Surico \& Galeotti, 2020). The impact will vary from country to country and most likely increase poverty and inequalities at a global scale. In this situation, the role of Islamic social finance even more urgent. Some of assesments under the Islamic social finance scenario might be applied we highlight as follows:

\section{Direct Cash Assistance (Cash Transfer)}

Distribution of direct cash assistance from zakat, infaq and sadaqah, from zakat collection units and from the society. Facing the current situation, not only the government is engaged, but also the society is expected to contribute according to their respective abilities and conditions. In this context, it takes sacrifice from the rich and patience from the poor affected by the plague, on the basis of love which is manifested in the form of solidarity among humans, where people who are more fortunate help those who are less fortunate (Linge, 2015). One of the forms, during the COVID-19 pandemic, is by paying/giving zakat, infaq, and sadaqah. Specifically for zakat that is paid, its distribution can be focused directly on the poor who are directly affected by COVID-19, as one of the groups entitled to receive zakat (zakat recipient or mustahiq). This is an Islamic Economic philanthropy scheme that has great potential for the economy of the society. But unfortunately, the realization of zakat entering BAZNAS is still far from expectations. Realization of zakat at the end of 2018 was recorded at only Rp. 8.1 trillion, even though the potential reached Rp. 252 trillion. For this reason, the strengthening of the zakat, infaq and șadaqah funds campaign can continue to be intensified.

\section{Strengthening Infaq Programs}


The most affected groups by the pandemic are those in informal sectors and microsmall enterprises who are categorized as vulnerable non-poor people, which become poor due to forced unemployment, business slowdown and bankruptcy, so that the number of mustahiq (poor people supported by zakat) increase drastically, while the number of muzakki (zakat payers) decrease. Consequently, the collection of zakat declines, while the need of zakat by mustahiq increases. Therefore, the role of infaq as voluntary donation (not mandatory) has increased in importance, which is more flexible due to the absence of special terms and conditions such as zakat, and it could become an alternative to encourage Islamic philanthropy in the community.

The strengthening strategy of social fundraising in the form of infaq for various programs in the society is expected to be leveraged in decreasing zakat collection. Therefore, governments and related institutions such as BAZNAS, private zakat institutions (LAZ), Zakat Collection Unit (UPZ), and other social community agencies can pursue the strengthening of this infaq to support various programs. Infaq could also be used to complement productive zakat providing qard for mustahik to develop their micro businesses to be able to get out of poverty and become self sufficient. In longer term, infaq could also be used to complement the establishment of productive waqf to cover initial operating costs needed, before it finally generates profits.

All stakeholders need to move together to build collective awareness and solidarity during the COVID-19 pandemic through infaq and charity as a strengthening effort for affected communities, especially in the most major aspects, such as the emergency responses, the food security in the form of staple food, free meals and public kitchen, procurement of personal protective equipment (PPE) for medical personnel, masks, handsanitizer, spraying disinfectants in public areas, as well as education to the community. This division of staple food needs can be an early stage. The next stage, the medium-term stage, is establishing community independence, one of them through 'Infaq Bank'.

Among the efforts that can be done to strengthen the infaq donation in the community is the use of digital platform. Large-scale social restrictions (PSBB), social distancing and Work from Home (WFH) have caused space constraints to meet, so that zakat and other social institutions need to optimize digital channels (digitisation). These digital canals have actually been in use since a few years ago, but have not been seen as an important investment or very urgent, so it is managed only the awareness-based community. In the pandemic era of COVID-19, the shifting of direct or offline transactions or face to face to online and digital transactions is inevitable, demanding cooperation between the management of social funds and provider of digital platforms to support and strengthen public awareness in utilizing the use of digital platforms to collect and distribute Islamic social funds, including zakat, infaq and cash waqf.

\section{Strengthening Waqf Programs}

Strengthening waqf programs, including cash waqf for social waqf projects, productive waqf, combanation of social and productive waqf, or cash waqf linked sukuk needs to be improved. The Indonesian Waqf Board (BWI) needs to work with sharia financial institutions to promote this waqf scheme, which in turn can be used for the construction of various waqfbased infrastructure such as Waqf Hospital specifically for victims of COVID-19, Waqf 
Personal Protective Equipment, waqf masks, waqf polyclinics, Isolation Houses Waqf, procurement of waqf ventilators, waqf universities and others. Waqf management must be done professionally, so that waqf can be used productively and sustainably, given the reality that a lot of waqf property exists, but it is lacking and not even productive, so it is not maximally beneficial (Sakni, 2013).

In fact, with current developments, waqf can be in the form of any object of economic value, including patents as productive waqf. If it is time for a vaccine for COVID-19 to be discovered, it is hoped that the patent can be represented, so that it can be used for the entire world community. Therefore, it is important to campaign the importance of waqf during the COVID-19 pandemic outbreak to the public including scientists and inventors (vaccine researchers).

As is known, waqf has a very large role in infrastructure development in various public facilities and economic empowerment of the people (Asri et al., 2020), where cash waqf is an alternative that is expected to overcome the problem of poverty in the society (especially for those affected by COVID-19), with active participation of non-governmental parties (communities) especially the rich and have the ability to help alleviate the suffering of the poor and business. In order to optimize the role of waqf in the development of pandemic impacts, the Indonesian Waqf Agency along with a number of national stakeholders, launched the Indonesian Caring Waqf Movement, abbreviated KALISA (BWI, 2021). As a national program, KALISA is a national money waqf movement, where the waqf of money collected will be placed in Islamic financial investment instruments so that the basic needs of waqf will be maintained and the investment proceeds will be channeled in the form of beneficiary programs. In this period, the distribution objective is focused on handling and recovering the impact of the Covid-19 pandemic experienced by the community, both in the field of health, education and socioeconomics.

In other that, study by Kusmayadia and Noviyanti (2021) that collected data from nearly 56 people or about 17 heads of families were laidoff from their factories or workplaces and returned home, spread from various cities in Indonesia with various professions, found that the NU Branch Management together with the Wandanpuro Government agreed that some of the managed waqf management results would be given to the layoff victims from their factories or workplaces and returned to their villages who were domiciled in Wandanpuro, with the aim of easing the economic burden as well as helping their economic recovery. The assistance provided was in the form of food and financial assistance obtained from the management of productive waqf managed by the Wandanpuro NU Branch. Although the assistance provided was not much the people who received the assistance really needed it because after all they were no longer earning since they were laid off and or their business was no longer running due to the impact of the Covid-19 pandemic.

With the use of digital technology today, zakat, infaq and waqf is potentially optimized in times of the COVID-19 pandemic crisis. With the digital technology, the middle-upper community which is classified as muzakki can be temporary facilitated, poor group that becomes victim of pandemic can also be helped. The digitisation of zakat allows for the service of the muzakki and mustahik to be carried out without direct face interaction. Mustahik no need to visit the counter of zakat and amil of zakat do not need to meet up the mustahik to share the zakat funds. Thus, zakat can be optimized in helping to meet the basic 
needs of poor people affected by COVID-19 in all affected areas of Indonesia, and at the same time supporting social distancing policies. Among the innovations that can be done is through mobile banking, internet banking, marketplace, online payment or utilization of crowd funding platforms such as Kitabisa.com as an effective medium in the collection and distribution of zakat. With digital platforms, some related parties such as muzakki, amil and mustahik can be integrated in a single application. Thus, the national ecosystem of zakat will be formed digitally and broadly without any territorial or regional restrictions. In the end, the management of digital-based zakat, especially in the current situation, is expected to assist in reducing the spread impact of the COVID-19 outbreak which is still a major threat to Indonesia.

\section{Superior Business Capital Assistance During the Crisis}

In the midst of crisis, a lot of business sectors or Micro and Small Enterprises (MSEs) are struggling to survive. These businesses are often difficult to survive because of limited capital. The existence of MSMEs as a non-muzakki group is a group that is very vulnerable to falling into the abyss of poverty and bankruptcy due to economic shocks. Thus, the number of mustahiq can increase very sharply, while the number of muzakki can continue to decline significantly (Ascarya, 2020).

The existence of small and medium micro entrepreneurs, especially traders in traditional markets is a form of economic life for most of the people of Indonesia. This position has placed traditional market traders as the main thing that should get attention, especially in terms of capital. The process of developing traditional market traders is a manifestation of economic development that has become very important. Efforts to develop and strengthen the potential of traditional market traders as strategic economic groups must be oriented towards empowerment, so that it enables to form local economic actors who are independent and strong through Microfinance Institution (LKM) especially Sharia Microfinance Institution (LKMS) (Sabirin \& Sukimin, 2017).

Therefore, providing capital to businesses is used as a means of reducing the impact of the crisis. Provision of capital can be done with several policy alternatives, such as providing additional stimulations of sharia banking relaxation and restructuring or suspension of sharia credit/financing payments for the next few months. To be stronger, the provision of capital from banks/sharia financial institutions needs to be supported and strengthened with mentoring or assistance so that it can be accounted for.

Bank Wakaf Mikro (BWM) utilizes waqf funds and Islamic charity to provide microfinance programs for MSEs that have limited access to formal financial institutions. The study by Yumna, Marta, and Yanuarta that collected primary data obtained from semistructured interviews of 282 respondents consisting of 182 clients and 150 non-clients from BWM Al-Kausar in West Sumatra, Indonesia, and analyzed the data using the Difference in Difference (DID) method to compare the well-being of clients as treatment group and nonclients as control group before and during the pandemic, found that during this pandemic, there is an increase of wellbeing in both clients and non clients. The clients experienced a higher increase of well being compare the non clients but the changes of wellbeing before and during pandemic is not statistically significant between clients and non clients. This study 
contributes discussions in the literature on the importance of waqf to reduce the impact of a pandemic for MSEs through microfinance mechanism.

\section{Qarḍ al-Hasan Loan}

The above business capital can also be followed by a qardh al-hasan loan. In Islamic economic/financial terminology, qard al-hasan is a loan that does not take any benefit (profit) but is still emphasized to be paid back (Sari, 2015). This product or scheme is one of the products/schemes of the sharia financial system which is very important in supporting recovery or sustaining the economy. Among the channeling options that can be done is through:

1. Sharia Microfinance Institutions (LKMS) in financing nano businesses where funds can come from several sources, from the general public, private companies and State-Owned Companies (BUMN)/District-Owned Companies (BUMD);

2. Direct loans without margins, both for businesses and consumption distributed by the company (private or BUMN/BUMD) to its employees or partners (such as online motorcycle-taxi drivers) where the fund can come from Corporate Social Responsibility (CSR) fund or other sources. To increase CSR funds, the government needs to reinforce CSR obligations and higher contributions from BUMN/BUMD and private companies. In the Islamic view, business activities are part of religious obligations. Social responsibility refers to the obligations under which the organization must protect and contribute to the society where the organization is located. In Islam, the concept of brotherhood and social justice is known, which can be done by sharing profits / prosperity with the surrounding community. In that way, a company has implemented its social responsibility;

3. Baitul Māl wa Tamwīl (BMT), through its Baitul Mal it becomes one of the institutions that can participate in providing solutions to this problem, namely by implementing empowerment programs through the products of qard al-hasan. The implementation of qard al-hasan does not only function as a financing institution but also this form of financing is equipped with a mentoring model, so that with this mentoring the implementation of the financing model can run well and, in the end, this noble goal will also be realized.

\section{Increasing the Islamic Economic and Financial Literation}

Sharia Economic and Financial System as a system that is full of values as well as guidance from God is believed to be able to realize productive economic activities within the framework of justice. For this reason, the general public needs to be given a correct understanding of sharia economics and finance in order to increase sharia economic and financial literacy, including through the provision of sharia economic education assistance to students affected by COVID-19; also by granting licenses and facilities for State and Private Universities to run the Long Distance Program (PJJ, Program Jarak Jauh) that offers the Sharia Economic program with an emphasis on moral development; and the expansion of internet connection infrastructure that supports PJJ evenly throughout Indonesia for free.

Besides, the existence of Sharia Economic Community Organization as a forum aimed at being a reference and being followed as an example for efforts to accelerate the development 
and application of the economic system and Islamic business ethics in Indonesia enables the forum to be involved in these efforts. Sharia Financial Literacy in Indonesia is still categorized as low, occupying only the ninth position in the market share of sharia finance in the world. Because the level of knowledge and technology of Indonesian society is also still lacking, many people are not yet aware of the existence of sharia financial products that are very useful for life.

\section{Development of Sharia Financial Technology}

The development of sharia financial technology to smooth the liquidity of sharia online market participants, while at the same time an increased focus on social finance (zakat, infaq, sadaqah and waqf) besides commercial finance. Also included in this case is the development of a market place to gather traditional and MSME markets which number nearly 60 million today, with the aim of bringing together demand and supply both domestically and abroad, especially in the lockdown period due to the pandemic. Moreover, existing research says that problems of finance, human resources, and technology have become classic problems faced by Micro and Small Enterprises (MSEs) in Indonesia. Technological developments in finance have evolved in recent years and have caused changes of people's behavior in financial transactions. This can be a solution for the financial problems faced by Micro and Small Enterprises (MSEs).

\section{Condition After Zakat, Infaq, Sadaqah and Waqf Intervention}

When a mustahiq who receives zakat already has the ability to spend wealth to meet his needs, then this condition will cause the Demand curve to shift to the right from $\mathrm{D}^{0}$ to $\mathrm{D}^{1}$. On the other hand, when a muzakki has assets, he is motivated to invest those assets in the real sector so that the supply of goods and services will increase and the supply curve will move to the right, from $S^{0}$ to $S^{1}$.

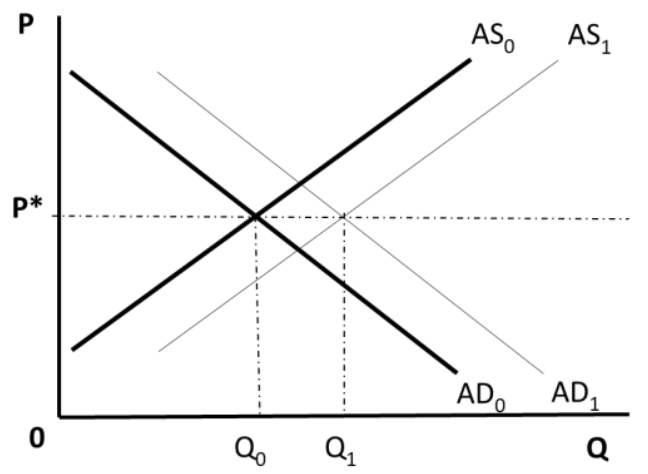

(1) 


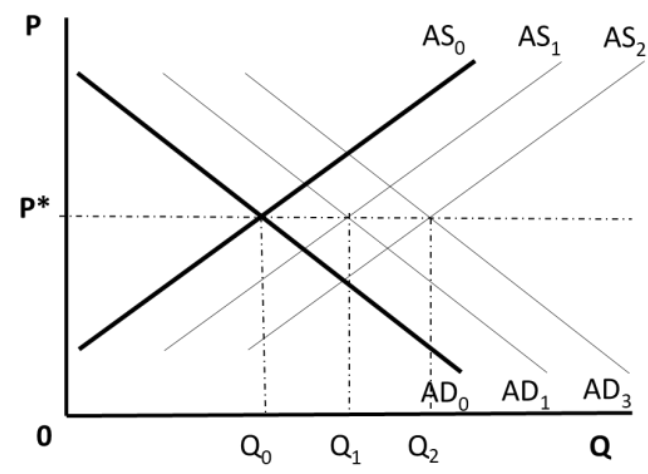

(2)

Figure 2: Zakat, infaq, șadaqah and waqf Intervention in Demand and Supply Curve Source: Ascarya (2020)

Then, in the next zakat payment period, mustahiq still has the ability to spend assets to meet his needs, so the demand curve will continue to shift to the right from $\mathrm{D}^{1}$ to $\mathrm{D}^{2}$. This will take place continuously. Similarly, the supply side will also move to the right, from $S^{1}$ to $S^{2}$, and continues to move. In the end, a continuous movement of demand and supply sides to the right will gradually increase GDP or per capita GDP that leads to welfare and prosperity.
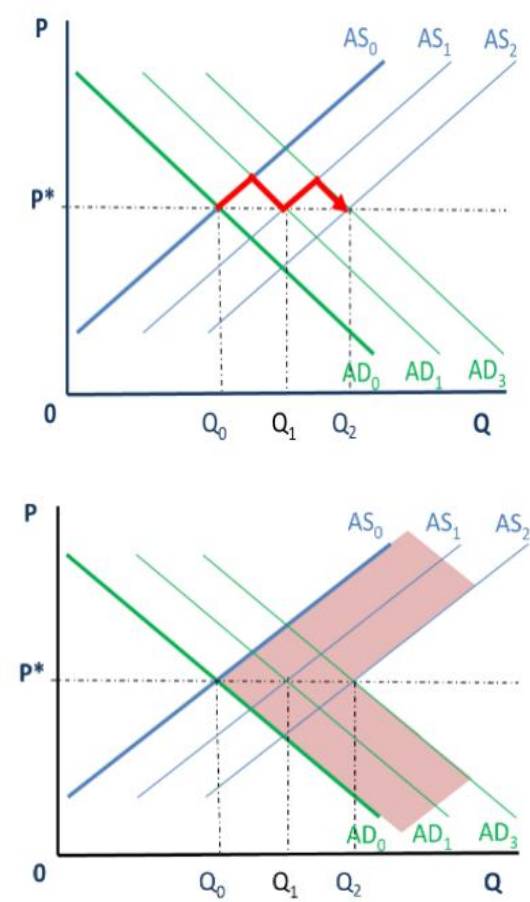

Figure 3. Final Condition of Economy with ZISWAF Intervention Source: Surico \& Galeotti (2020)

In the end, if the above programs, especially direct cash assistance, zakat, infaq, waqf, or CSR, for the community and the business sectors or Micro and Small Enterprises (MSEs), can really be promoted, then it is expected to increase aggregate demand and aggregate supply back to the right, followed by the development of an online market that focuses on 
MSMEs that bring together supply and demand, so that the economic surplus is re-shaped and helps accelerate economic recovery.

\section{CONCLUSION AND RECOMMENDATION}

As a country with the largest Muslim population in the world, Indonesia and its Muslims can provide their best role through various forms or models of philanthropy in Islamic social economic and finance, especially during the COVID-19 pandemic. This role is expected to overcome the economic shocks that occur and the whole community, especially Muslims, can participate in contributing to mitigate these shocks. Among the solutions that can be offered within the framework of the concept and system of Islamic Social Economics and Finance are: (1) by channeling direct cash assistance from zakat, infaq, and sadaqah; (2) by strengthening infaq; (3) by strengthening waqf in the form of money waqf, productive waqf, waqf-linked sukuk or waqf for infrastructure; (4) through superior venture capital assistance for the business sectors or Micro and Small Enterprises (MSEs); (5) through the qard al-hasan scheme; (6) improvement of sharia economic and financial literacy; (7) through the development of Islamic financial technology. If the above programs, especially direct cash assistance, zakat, infaq, waqf, or CSR, can really be encouraged, then it is hoped that they will help the economic surplus to be re-established so that the acceleration of economic recovery can be realized.

Some of the policy recommendations that can be offered based on the explanation above as follow:

First, among the efforts that can be done in the strengthening of the zakat, infaq and șadaqah are:

1. Make the mosque the center of baitul maal for the surrounding community and must be registered as a zakat Collecting Unit under the coordination of the zakat Management Organization. Even though mosques are currently not functioning, in this era of social media mosque worshipers can still be mobilized by paying zakat online;

2. Literacy related to the calculation of zakat can be strengthened by the establishment of zakat Centers in mosques and campuses;

3. It is necessary to call for a national and massive Solidarity Fund movement which can be led directly by the President of the Republic of Indonesia which is supported by all national mainstream media or official government and community social media. If zakat involves two parties, namely the government or its representatives, in this case amil zakat (Baznas), and zakat payer (muzakki), then infaq and șadaqah are more flexible, because they only come from one party, namely the payer/giver of infaq or sadaqah, so that collection and distribution can be carried out more optimally for the communities affected by COVID-19.

Second, specifically for the cash waqf linked sukuk, related parties such as BWI, the Ministry of Finance, Bank Indonesia, national sharia banks that become Sharia Financial Institutions Receiving Money Waqf and Operational Bank of Badan Wakaf Indonesia (BWI), and Nazhir Productive Waqf who are BWI Partners in collecting waqf funds, can initiate cooperation or agreement related to two things. Firstly, the acquisition of profit sharing from the sukuk invested, by BWI it will be used as much as possible for social and health programs 
in order to mitigate the impact of COVID-19. Secondly, the government can utilize the results of the issuance of SW series State sukuk to finance the State Budget (APBN), particularly in financing the construction or provision of public service facilities and infrastructure affected by COVID-19, as mentioned above.

Third, the unprecedented global pandemic will force the Islamic finance industry to adapt in order to sustain its presence in the global economic and financial system. Islamic financial institutions must integrate Islamic social finance such as zakat and waqf into their operations in order to provide a community-based social security system that will help to maintain livelihoods, basic needs, and purchasing power of the society. If this potential is materialized, it could significantly help to take care of those in need as a result of this crisis. Meanwhile, waqf potential in Indonesia is equally big, with assets in the form of land alone reaching up to $510 \mathrm{~km} 2$. If waqf lands are utilized productively for agriculture, it could support basic needs provision in Indonesia during times of crises.

Fourth, regarding of acceleration and delay of collecting zakat policy by Umar ibn Khattab on the basis of the benefits (maslahat) for the Mustahik as mentioned above, in fact relevant to the policy of management of zakat in Indonesia, especially in the conditions and context of the current pandemic crisis. The payment of zakat can be accelerated before a year (haul) and after enough of the nisab, considering the existence of great benefits for the poor people who affected by pandemic outbreak of COVID-19 in Indonesia. The government, in this case the National Board of Zakat (LAZNAS), may collect the of zakat to be channeled to the Mustahik.

The limitation of this research lies in the discussion that is still dominated by the theoretical approach. Although the discussion has been equipped with several examples of applications related to the role of Islamic economics and finance in countering the impact of the pandemic in Indonesia, it is still not adequate. Therefore, future research is expected to further explore how the role and application of Islamic economic and financial programs and policies in countering pandemic impacts for the economy, health, education and other areas. In addition, future studies are also expected to provide data and experience from other countries in comparison so as to produce better and effective policy recommendations in the future.

\section{REFERENCES}

Al-Haritsi, J. (2006). Fikih Ekonomi Umar bin al-Khatab. Jakarta: Khalifa (Pustaka Al Kautsar Grup).

Ascarya, A. (2017). Baitul Maal Wat Tamwil (BMT): An Integrated Islamic Social and Commercial Financial Institution in Indonesia. 2nd International Statistical Institute (ISI) Regional Statistics Conference, ISI-Bank Indonesia, Bali, Indonesia, March 2124, 2017.

Ascarya, A. (2020). The Role of Integrated Islamic Commercial and Social Finance in Times
of
Covid-19
Outbreak.
PEBS-UI.
p.29-30.

https://doi.org/10.13140/RG.2.2.24378.62400

Asri, A., Aqbar, K., \& Iskandar, A. (2020). Hukum dan Urgensi Wakaf Tunai dalam Tinjauan Fikih. BUSTANUL FUQAHA: Jurnal Bidang Hukum Islam, 1(1), 79-92. 
Baldwin, R., \& Mauro, B. W. di. (2020). Economics in the Time of COVID-19. The Graduate Institute Geneva (CEPR Press). p. 1-10.

Bank Indonesia. (2020). Indonesia's Recent Economic Updates, Prospect, and Bank Indonesia's Policy Mix’. doi: 10.1017/CBO9781107415324.004.

BWI (Badan Wakaf Indonesia). (2021). Badan Wakaf Indonesia Meluncurkan KALISA Sebagai Gerakan Wakaf Nasional Untuk Membantu Penanganan Covid-19. https://www.bwi.go.id/5126/2020/07/08/badan-wakaf-indonesia-meluncurkan-kalisasebagai-gerakan-wakaf-nasional-untuk-membantu-penanganan-covid-19/. Accessed on 9 September 2021.

Cavanagh, S. (1997). Content analysis: concepts, methods and applications. Nurse Researcher, 4(3), 5-16.

Downe-Wamboldt, B. (1992). Content analysis: method, applications, and issues. Health Care for Women International, 13(3), 313-321.

Elo, S., \& Kyngäs, H. (2008). The qualitative content analysis process. Journal of Advanced Nursing, 62(1), 107-115.

Fanidi, A., Jouven, X., \& Gaye, B. (2020). Strategies to control COVID-19 and future pandemics in Africa and around the globe. European Heart Journal.

Fernandes, N. (2020). Economic effects of coronavirus outbreak (COVID-19) on the world economy. Available at SSRN 3557504.

Gershon, D., Lipton, A., \& Levine, H. (2020). Managing covid-19 pandemic without destructing the economy. ArXiv Preprint ArXiv:2004.10324.

Gros, C., Valenti, R., Valenti, K., \& Gros, D. (2020). Strategies for controlling the medical and socio-economic costs of the Corona pandemic. ArXiv Preprint ArXiv:2004.00493.

Hsieh, H.-F., \& Shannon, S. E. (2005). Three approaches to qualitative content analysis. Qualitative Health Research, 15(9), 1277-1288.

Institut Tazkia. (2020). Tujuh Paket Ekonomi dan Keuangan Syariah Mengatasi Dampak Krisis COVID-19. Bogor: Institut Tazkia.

Iskandar, A., \& Aqbar, K. (2019). Kedudukan Ilmu Ekonomi Islam di Antara Ilmu Ekonomi dan Fikih Muamalah: Analisis Problematika Epistemologis. NUKHBATUL'ULUM: Jurnal Bidang Kajian Islam, 5(2), 88-105.

Iskandar, A., Possumah, B. T., \& Aqbar, K. (2020). Peran Ekonomi dan Keuangan Sosial Islam saat Pandemi Covid-19. SALAM: Jurnal Sosial dan Budaya Syar'i, 7(7).

Jewell, M. L., Jewell, M. L., \& Singer, R. (2020). Practice management during a pandemic: common issues that affect all of us. Aesthetic Surgery Journal Open Forum, 2(2), ojaa017.

Jones, C. J., Philippon, T., \& Venkateswaran, V. (2020). Optimal mitigation policies in a pandemic: Social distancing and working from home. National Bureau of Economic Research.

Kasdi, A. (2016). Filantropi Islam Untuk Pemberdayaan Ekonomi Umat (Model Pemberdayaan ZISWAF di BMT Se-Kabupaten Demak). Iqtishadia: Jurnal Kajian Ekonomi Dan Bisnis Islam STAIN Kudus, 9(2), 227-245.

Kusmayadia, R.C.R., Noviyanti, R. (2021). The Impact of Productive Waqf During the Covid-19 Pandemic (Case Study of Waqf Organizerat Wandanpuro Bululawang). Iqtishodia: Jurnal Ekonomi Syariah, 6(1): 23-28. 
Linge, A. (2015). Filantropi Islam Sebagai Instrumen Keadilan Ekonomi. Jurnal Perspektif Ekonomi Darussalam, 1(2), 154-171.

Morgan, D. L. (1993). Qualitative content analysis: a guide to paths not taken. Qualitative Health Research, 3(1), 112-121.

Muzakki, F. (2020). The Global Political Economy Impact of Covid-19 and The Implication to Indonesia. Journal of Social Political Sciences, 1(2), 76-92.

Obaidullah, M. (2008). Introduction to Islamic Microfinance. New Delhi: IBF Net Limited.

Obaidullah, M. (2008). Role of Microfinance in Poverty Alleviation: lessons from experiences in selected IDB member countries. Jeddah: IRTI IDB

Obaidullah, M., \& Khan, T. (2008). Islamic Microfinance Development, Challenges and Initiatives. Dialogue Paper Policy Dialogue Paper 2. Saudi Arabia: Islamic Research and Training Institute-Islamic Development Bank.

Sabirin, S., \& Sukimin, D. A. (2017). Islamic Micro Finance Melati: Sebuah Upaya Penguatan Permodalan bagi Pedagang Pasar Tradisional. Economica: Jurnal Ekonomi Islam, 8(1), 27-53.

Sadeq, A. M. (1997). Poverty alleviation: an Islamic perspective. Humanomics.

Sakni, A. S. (2013). Konsep Ekonomi Islam dalam Mengentaskan Kesenjangan Sosial: Studi atas Wacana Filantropi Islam dalam Syari'at Wakaf. Jurnal Ilmu Agama: Mengkaji Doktrin, Pemikiran, Dan Fenomena Agama, 14(1), 151-166.

Sari, S. P. (2015). Pengaruh Pembiayaan Qardhul Hasan Terhadap Peningkatan Pendapatan Usaha Mustahik Zakat (Studi Kasus Dompet Peduli Umat Daarut Tauhiid Cabang Bogor). AL-INFAQ, 4(1), 57-93.

Schreier, M. (2012). Qualitative content analysis in practice. Sage publications.

Sukmana, R., Indrawan, I.W., Ajija, S.R. (2020). The Impact of COVID-19 Outbreak on The Islamic Financial Industry: Indonesia, in the Book Entitled "Impacts of COVID-19 Outbreak on Islamic Finance in the OIC Countries". Jakarta: KNEKS. p. 43-51.

Surico, P., \& Galeotti, A. (2020). The economics of a pandemic: the case of Covid-19. Wheeler Institute for Business and Development, LBS. London: London Business School.

Uyun, Q. (2015). Zakat, Infaq, Shadaqah, dan Wakaf Sebagai Konfigurasi Filantropi Islam. Islamuna: Jurnal Studi Islam, 2(2), 218-234.

Weber, R. P. (1990). Basic content analysis (Issue 49). Sage.

Yumna, A., Marta, J., and Yanuarta, R. (2021). The Roles of Waqf for Sustaining Well-Being During Covid-19 Pandemic: Empirical Evidences From Indonesia. Proceeding: $5^{\text {th }}$ The Annual Islamic Finance Conference (The AIFC). 